\title{
A novel framework of e-participation for smart cities
}

\author{
Muhammad Yusuf a,1,*, Nurwahyu Alamsyah ${ }^{\text {b,2 }}$, Muh. Syarif c,3, Arif Muntasa d,4, \\ Hakam Muzakki e,5 \\ ${ }^{a}$ Department of Information System, Universitas Trunojoyo Madura, Bangkalan, Indonesia \\ ${ }^{\mathrm{b}}$ Department of Information Management, National Taiwan University of Science and Technology, Taipei, Taiwan \\ ${ }^{\mathrm{c}}$ Department of Management, Universitas Trunojoyo Madura, Bangkalan, Indonesia \\ ${ }^{\mathrm{d}}$ Department of Informatics, Universitas Trunojoyo Madura, Bangkalan, Indonesia \\ ${ }^{\mathrm{e}}$ Department of Mechanical Engineering, Universitas Trunojoyo Madura, Bangkalan, Indonesia \\ ${ }^{1}$ muhammadyusuf@trunojoyo.ac.id*; ${ }^{2}$ D10709802@ mail.ntust.edu.tw; ${ }^{3}$ syarif@trunojoyo.ac.id; ${ }^{4}$ arifmuntasa@ trunojoyo.ac.id; ${ }^{5}$ muzakki.h@gmail.com \\ * corresponding author
}

\begin{abstract}
ARTICLE INFO
ABSTRACT

Article history

Received August 14, 2019

Revised September 9, 2019

Accepted November 1, 2019

Keywords

Novel framework

e-participation

Smart cities

The smart city is an exciting concept for improving the quality of the city. However, a smart city needs participation from citizens and all related stakeholders to use the technologies effectively in order to achieve the goal and solve the problems. Even though the city already has high-tech infrastructures, participation still required to provide ideas, inputs, and roles within the development of smart city concepts. This research aims to describe and analyze the current state of the e-Participation frameworks and propose a novel framework for smart cities. The analysis will go through a systematic literature review. Hopefully, this study makes contributions by providing a novel framework of e-Participation for smart cities. This research has implications for theory and practice. For theory, the novel framework can be added to the body of knowledge of e-participation, e-government, and smart cities fields. For practice, the framework will be useful for practitioners, policymakers, people and other stakeholders related to the smart city governance to increase citizen participation through technology-based services.
\end{abstract}

This is an open access article under the CC-BY-SA license.

\section{Introduction}

There is a growth of research interests regarding the use of information and communication technologies as the channels for social and political participation. ICT have revealed themselves as the primary tool for social and political activities. Many political parties and government stakeholders in some countries are using ICT as the main instrument to get closer to the voters and citizens. Obama's 2008 and Joko Widodo's 2014 electoral campaign are well-known examples of the excessive use of the internet to campaign their programs and interact with their constituents.

Citizens have various chances to communicate directly with the government to influence the policy-making process through the internet. The United Nations (UN) has surveyed governments worldwide in order to assess their role in facilitating citizens to participate actively in policy-making processes. The study examines E-Participation Index to evaluates some points as follows: (i) the online provision of information by the government to the citizens, (ii) the online communication with stakeholders, (iii) and the extension of online communication results as a direct input for public policy [1]. It aims to support active citizen participation with the latest technology developments in order to promote a fair, effective, and efficient society and government, which is called e-participation. This field focuses on the use of technologies to expand citizen participation activities from limited and offline participatory activities to online, borderless and active participation. 
In the research community, there are various definitions of e-Participation. e-Participation is the extension and transformation of participation in societal democratic and consultative processes mediated by information and communication technologies (ICT), primarily the internet [2]. It aims to support active citizenship with the latest technology developments, increasing access to and availability of participation in order to promote fair and efficient society and government [2]. On the other hand, the definition of e-Participation within a school as the various activities of interaction, communication, and participation between numerous internal and external school stakeholders through several electronic technologies that are influencing and influenced by many complex factors, support systems, and change factors [3].

The advantages of the internet for improving citizen participation can be summarized into four main points: (i) It ease and speed up people to get information on public issues. (ii) It also facilitates the engagement in political participation by reducing the cost of social pressure, such as an individual can privately sign a petition on a controversial issue from his computer at home [4]; (iii) individuals can encourage others to participate through online platforms, such as Change.org or disseminate information through their social networks; (iv) the internet facilitates activities at the global scale and complements today's social report of collective action .

There are several existing e-Participation frameworks, such as Macintosh captured three levels of participation within e-democracy initiatives [5]; Tambouris et al., presented democratic processes, participation areas, participatory techniques, categories of used tools and ICT technologies [6]; Sæb $\varnothing$ et al., examined elements of e-participation, such as participation actors, activities, effects, evaluation, and contextual factors [2]; Kalampokis et al., described three domains model of e-Participation consist of the stakeholders, participation processes and ICT tools [7]; Phang \& Kankanhalli, discussed about three step procedures for e-Participation implementation [8]; Islam proposed a sustainable eParticipation implementation model [9]; Scherer \& Wimmer developed six-steps for e-Participation initiatives [10]; they also examined the holistic engineering approach for supporting the development of new e-Participation projects [11]; Salamat and Hasan proposed a framework based on ActorNetwork Theory (ANT) perspective within Malaysia context [12]; Medaglia developed a model based on the previous works [2], [13]; Yusuf et al., proposed a framework consist of relationships between government institutions and people through technology and its complex factors [14]; Yusuf et al., developed a model for e-Participation within school [3]; Scherer \& Wimmer, proposed a met model for the e-Participation framework [15]. As a summary, each of the previous frameworks captures different elements, things, and priorities.

E-Participation is also used by a government to gain citizens' participation. Recently, many governments transformed their cities to be a smarter city. Smart governance encourages various stakeholders in decision making and public services [16]. ICT-mediated governance, also called egovernance, is fundamental in bringing smart city initiatives to citizens, and to keep the decision and implementation process transparent.

Many cities in the world adopted this concept to have better service to the citizens. The concept of the smart city arose from the challenges and issues caused by the rapid urbanization of the world. A smart city aims to resolve various urban problems through ICT-based technology connected as urban infrastructure, such as public service unavailability or shortages, traffic, over-development, pressure on land, environmental or sanitation shortcomings, and other forms of inequality. The ultimate goal is to revitalize some of the city's structural problems such as environmental and social imbalances through the efficient redirection of information.

The concept of the smart city has attracted world interest, including governments, companies, universities, and institutes. Different stakeholders have tried to understand and explain the smart city from their different viewpoints. The term 'smart city' appeared for the first time in the early 1990s, and researchers have emphasized technology, innovation, and globalization in the process of urbanization [17].

There is a large body of research about smart cities, producing great innovation and implementations by many countries and cities. Smart cities also have potential benefits for the citizens by maximizing the usage of technology [18]. However, several key issues need to be addressed, such as concepts and success factors of a smart city that have not been discussed with a comprehensive understanding from multi-perspective, is based on our literature review about smart cities, such as 
previous work [17], [19]-[22]. Furthermore, many technology-based services were not utilized effectively by their citizens due to several factors.

As a consequence, the smart city requires a robust framework for e-Participation, which is limited research to examine this. Therefore, this research has a research question: How is the framework of eparticipation for sustainable smart city. Additionally, this research aims to address the gap aforementioned. Hopefully, this book chapter contributes by providing a novel framework of eParticipation for smart cities. The framework will have implications for theory and practice.

This book chapter consists of some sections as follows: Introduction, Research method, Results, and Discussions, as well as Conclusions and Contributions.

\section{Research Method}

This study uses systematic literature approach [23] and starts from abstract, introductions, literature review, problem identification, conducting the selection process, synthesize and write down the ideas proposed, and then make conclusions.

This research started through developing research design as following: literature reviews, define the research question, analysis, and evaluation of the previous frameworks, then develop a new framework. Moreover, analysis and discussions about the new framework and make conclusions, identification of the contributions and implications for the theory and practice.

In practice, we reviewed the previous frameworks of e-participation and smart cities. Moreover, we analyzed the relationship between e-participation, e-government, and smart city. Then, we identified the critical elements to develop a novel framework of e-Participation for smart cities.

Furthermore, this chapter began through the study of the smart city and e-Participation in order to choose the key concepts about:

- The word "smart" assumes a broad range of definitions because a smart city is a broad concept related to the different fields of applications. IBM reported that " the smart city is a broad concept including many aspects of urban life, such as urban planning, sustainable development, environment, energy grid, economic development, technologies, social participation and so on." [24]

- The terminology of the smart city is not identified if these terms can be adopted in the same cities, strategies, and technologies [19], [21], [25], [26].

- What is the definition, concept, and meaning of the smart city in several papers [27]-[38].

- E-Participation is a hybrid of various technologies, social and political measures, and there is a need to improve understanding of the relationships between these components and how their own evaluation practices can be applied to e-Participation as a whole [39].

- Participation can be generally understood as joining in, either in the sense of taking part in some communal discussion or activity or in the sense of taking some role in decision-making. EParticipation enabled and supported democratic initiatives, and related to communication services that are influenced by the rapid growth and acceptance of the Internet [40].

- The citizen participation have been adopted in the e-Participation process as following: community informatics, community building, collaborative environments, citizenship education, cultural politics, discourse, polling, voting, campaigning, electioneering, inclusion/exclusion, information provision, service delivery, policy processes, participatory law-making, citizen journalism, mediation, participatory spatial planning [6].

- Some categories were identified by examining the participation area from the more exclusive to the inclusive one as follows: expert administrations, elected representatives, professional stakeholders, lay stakeholders, randomly selected recruits, non-randomly selected recruits, and self-selected participants [6].

In this research, 362 references were obtained from various journals, books, conference proceedings, media reports, project reports, technical reports. The documents were collected from the Google Search Engine. Then, we searched the references by typing some keywords, such as smart 
city, framework, model, e-participation, performance, why the e-Participation framework is vital for the sustainable smart city, the central concept of e-participation, smart city development processes, and related models in cycles e-participation, e-government and smart city. Then, we divided into several classifications depend on the topic, and we have 45 relevant references, consist of 16 best papers of smart city and 29 best papers of e-Participation. From those 45 references, we used the references which have the framework and cited it in this paper for a literature review. Furthermore, we collected the previous frameworks of e-participation and smart city. Then, those frameworks were analyzed related to the advantages and limitations. Based on that analysis, we developed an eparticipation framework for a sustainable smart city based on the previous paper. Our proposed framework is a composite of several essential parts from the previous frameworks. Each framework has its superiority. The previous frameworks have some critical and unimportant parts, and then we took the most crucial part and combined it all into our proposed framework.

\section{Result and Discussion}

This study examines that e-Participation is one of the required fields regarding smart cities. Smart citizens use technologies for supporting their day to day activities, such as living in the regions with higher levels of public services online development, participating online via joining petitions, and taking part in public consultations.

Table.1 The advantages and limitations of previous models/frameworks

\begin{tabular}{|c|c|c|c|}
\hline Author(s)/Year & Model/Framework (s) & Advantage (s) & Limitation(s) \\
\hline $\begin{array}{l}\text { Macintosh, A., \& } \\
\text { Whyte, A. (2008) }\end{array}$ & $\begin{array}{l}\text { The three levels of analysis } \\
\text { for the e-Participation } \\
\text { framework [39] }\end{array}$ & $\begin{array}{l}\text { It explains the flow of the } \\
\text { process }\end{array}$ & $\begin{array}{c}\text { Too simple and it does not } \\
\text { explain more detail about the } \\
\text { participation areas, categories } \\
\text { of tools and sort of } \\
\text { technologies }\end{array}$ \\
\hline $\begin{array}{l}\text { Kalampokis et al., } \\
\text { (2008) }\end{array}$ & $\begin{array}{l}\text { A Domain Model for e- } \\
\text { Participation [7] } \\
\text { The UML class diagram } \\
\text { representing the domain } \\
\text { model for e-Participation }\end{array}$ & $\begin{array}{l}\text { The model describes the } \\
\text { primary and detail elements } \\
\text { of e-Participation process }\end{array}$ & $\begin{array}{c}\text { There are not complex factors } \\
\text { that influence the e- } \\
\text { Participation process }\end{array}$ \\
\hline $\begin{array}{c}\text { Sommer, L., \& } \\
\text { Cullen, R. (2009) }\end{array}$ & $\begin{array}{l}\text { The guide to Participation } \\
\text { [41] }\end{array}$ & $\begin{array}{l}\text { The model examines the } \\
\text { process and elements of e- } \\
\text { Participation process }\end{array}$ & $\begin{array}{l}\text { The model does not capture } \\
\text { the complex, geopolitical, } \\
\text { local, and change factors } \\
\text { which influence the e- } \\
\text { Participation implementation } \\
\text { projects. }\end{array}$ \\
\hline Bélissent, (2010) & Smart City Blue Print [19] & $\begin{array}{l}\text { The Blueprint includes two } \\
\text { essential aspects: education } \\
\text { and health }\end{array}$ & $\begin{array}{c}\text { There is no specific } \\
\text { information about citizens' } \\
\text { activities. }\end{array}$ \\
\hline $\begin{array}{l}\text { Nam, T., \& Pardo, } \\
\text { T. A. (2011) }\end{array}$ & $\begin{array}{c}\text { Fundamental Components of } \\
\text { Smart City Technology } \\
\text { Factors [25] }\end{array}$ & $\begin{array}{l}\text { Simple and clear to } \\
\text { understand, consists of three } \\
\text { parts: technology, human } \\
\text { and institution }\end{array}$ & $\begin{array}{l}\text { It is challenging to adopt the } \\
\text { idea for smart cities because } \\
\text { of technical issues. }\end{array}$ \\
\hline $\begin{array}{l}\text { Salamat, M. A., \& } \\
\text { Hassan, S. (2011). }\end{array}$ & $\begin{array}{l}\text { The e-Participation platform } \\
\text { based on Actor-Network } \\
\text { Theory (ANT) approach [12] } \\
\text { E-Participation framework } \\
\text { for public policy formulation }\end{array}$ & $\begin{array}{c}\text { Based on the ANT } \\
\text { perspective } \\
\text { According to the Malaysia } \\
\text { case study }\end{array}$ & $\begin{array}{l}\text { There are not geopolitical, } \\
\text { local, and change factors. }\end{array}$ \\
\hline $\begin{array}{l}\text { Scherer \& Wimmer, } \\
\text { (2011) }\end{array}$ & $\begin{array}{l}\text { Reference framework for e- } \\
\text { Participation projects [11] }\end{array}$ & $\begin{array}{l}\text { The model indicates the flow } \\
\text { of the process for e- } \\
\text { Participation implementation } \\
\text { projects. }\end{array}$ & $\begin{array}{l}\text { The model does not capture } \\
\text { the complex, geopolitical, } \\
\text { local, and change factors } \\
\text { which influence the e- } \\
\text { Participation implementation } \\
\text { projects. }\end{array}$ \\
\hline Batty et al., (2012) & $\begin{array}{c}\text { Typology of smart cities } \\
\text { functions [21] }\end{array}$ & $\begin{array}{l}\text { Consist of several issues } \\
\text { from different area }\end{array}$ & $\begin{array}{c}\text { Most of the information } \\
\text { describes theories. }\end{array}$ \\
\hline Medaglia, (2012) & $\begin{array}{l}\text { The shape of the e- } \\
\text { Participation field revisited } \\
\text { (2006-2011) [13] }\end{array}$ & $\begin{array}{l}\text { The model captures the } \\
\text { processes, factors, central } \\
\text { and detail of elements of e- } \\
\text { participation }\end{array}$ & $\begin{array}{l}\text { There are not geopolitical, } \\
\text { local, and change factors. }\end{array}$ \\
\hline
\end{tabular}




\begin{tabular}{cccc}
\hline $\begin{array}{c}\text { J. H. Lee, Hancock, } \\
\& \text { Hu, (2014) }\end{array}$ & $\begin{array}{c}\text { Case framework for smart } \\
\text { city analysis [22] }\end{array}$ & $\begin{array}{c}\text { Proposed by different point } \\
\text { of views, such as urban } \\
\text { openness, service } \\
\text { innovation, partnership } \\
\text { formulation, and urban } \\
\text { proactiveness }\end{array}$ & $\begin{array}{c}\text { This research leads to social } \\
\text { science research. Only a few } \\
\text { technological issues } \\
\text { emphasized. }\end{array}$ \\
\hline $\begin{array}{c}\text { Chuantao et al., } \\
\text { (2015) }\end{array}$ & $\begin{array}{c}\text { Classification of smart city } \\
\text { application domains [17] }\end{array}$ & $\begin{array}{c}\text { There were sub-domains in } \\
\text { every main domain. More } \\
\text { compact than Batty's } \\
\text { framework }\end{array}$ & $\begin{array}{c}\text { This framework is too broad } \\
\text { to implement, and no best } \\
\text { practice described there. }\end{array}$ \\
& & &
\end{tabular}

Furthermore, this research also analyzes the previous models/frameworks. Table 1 captures the advantages and limitations of the previous models/frameworks developed by other researchers regarding e-Participation and smart cities. Table 2 shows the various model/framework (s) related to e-Participation and smart cities.

Table.2 Previous Models/Frameworks by Other Researchers.

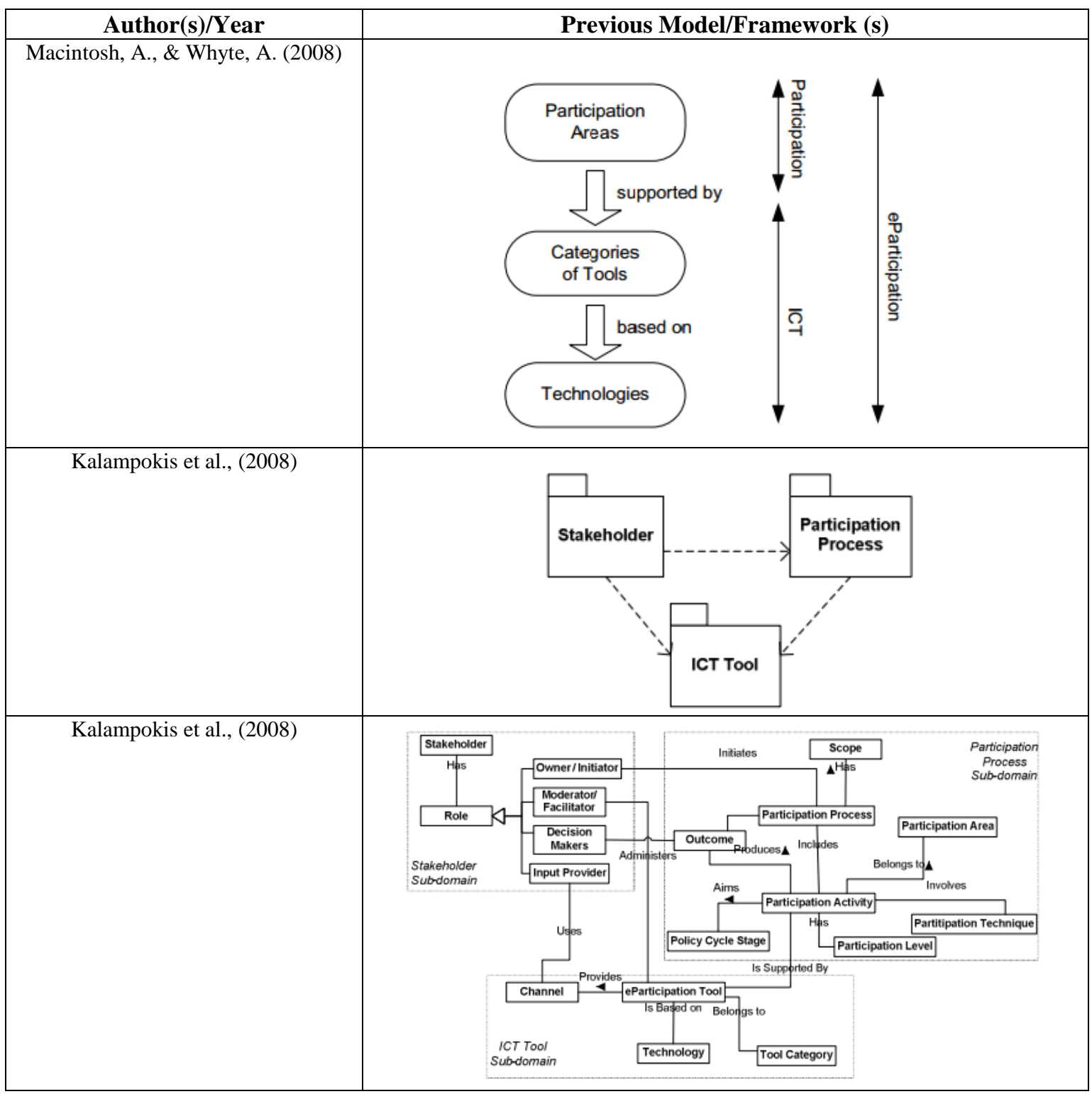



Vol. 3, No. 2, December 2019, pp. 45-55

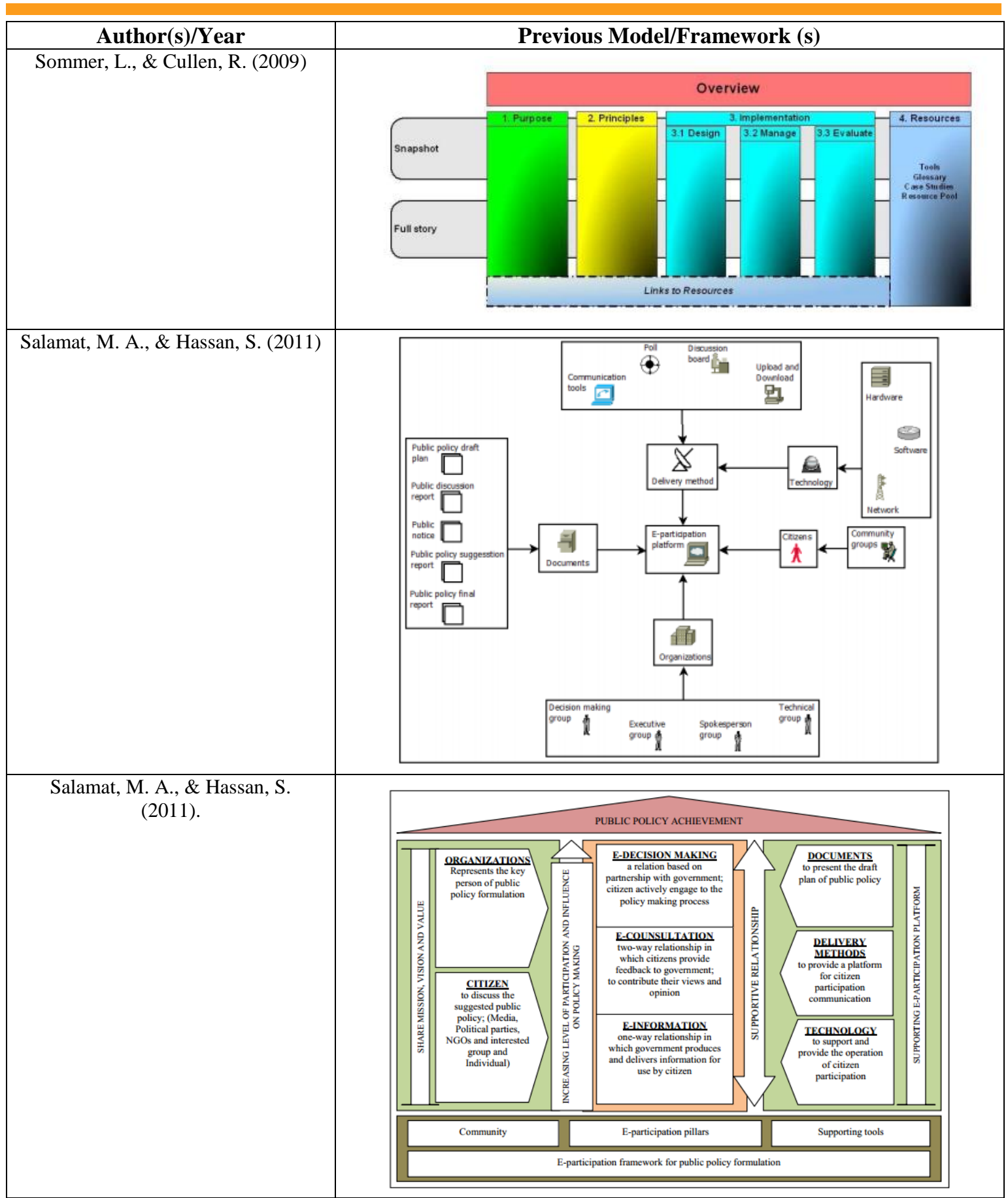




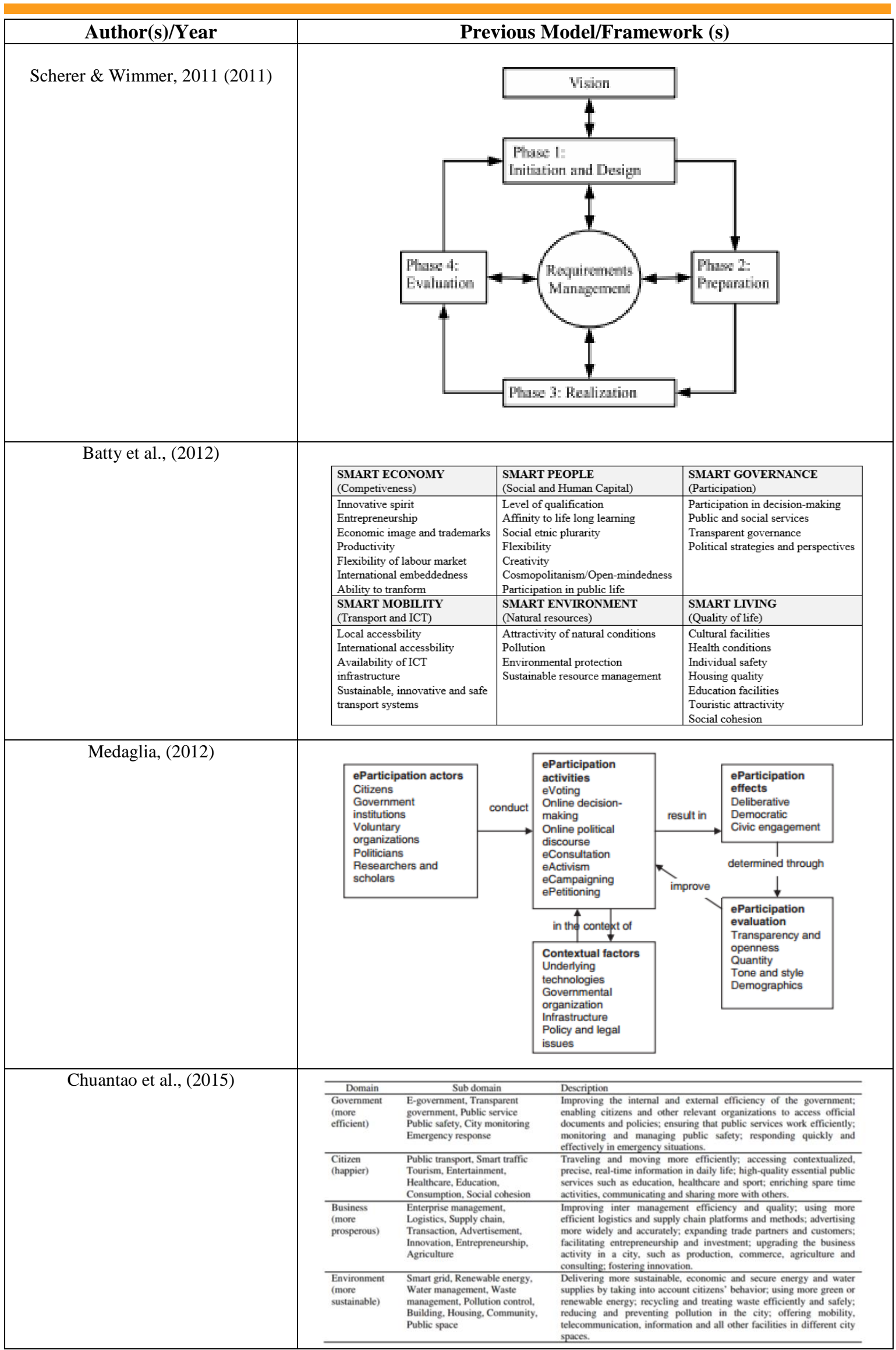




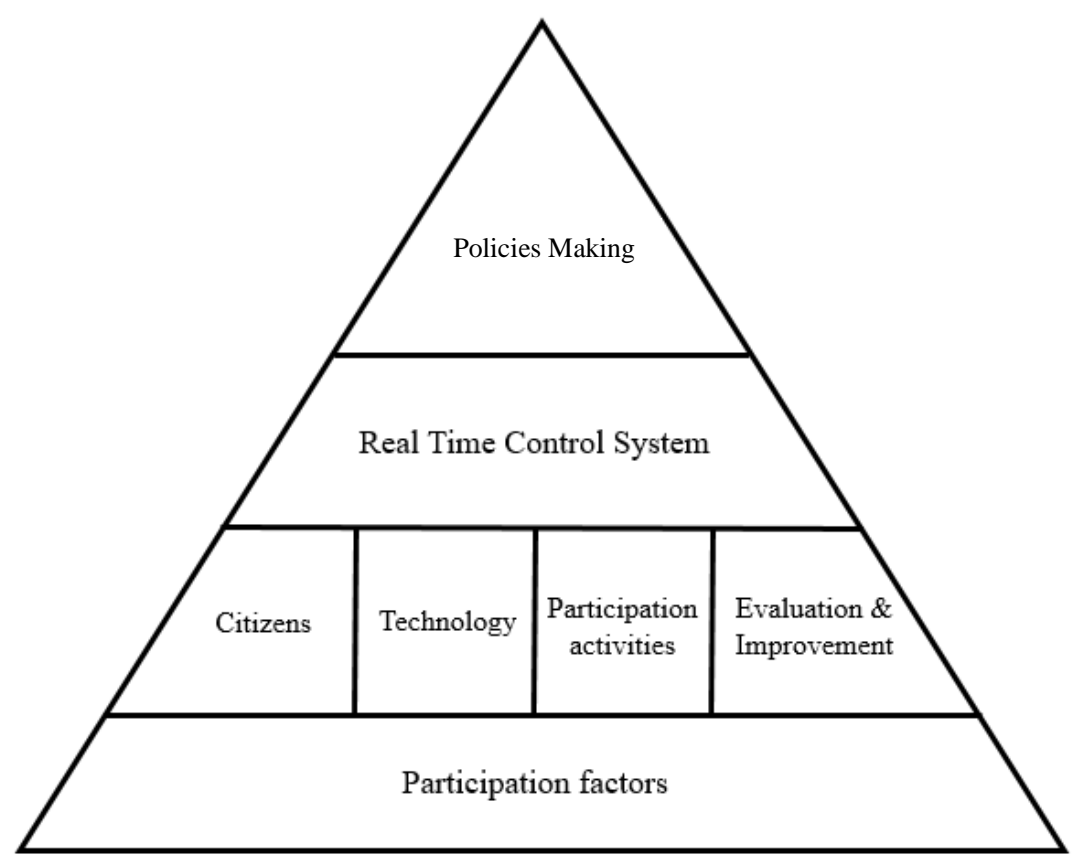

Fig. 1.The Proposed Framework of e-Participation for Smart Cities

Based on the analysis of the previous research regarding e-Participation and smart city, we developed a novel framework as shown in Fig. 1. This framework applies the e-Participation concept into the smart city field. The framework consists of four levels as following: the first level is participation factors; furthermore, the second one includes citizens, technologies, participation activities, and evaluations and improvements. Moreover, the third level is real-time control systems, and the fourth level is policymaking.

The first level is the participation factor. In the government system, some factors affect citizen participation. For instance, publishing the views of politicians, assessing the acceptance of these views on the constituents' side, making the views/objections on a political decision known by their constituents, ensuring transparency of political action, offering the opportunity to co-formulated political decision making in some instances, and others. Participation factors refer to the studies of the way governments are organized, and work affects to eParticipation.

The second level consists of citizens, technology, participation activities, and evaluations and improvements. The existence of actors and systems used in the e-Participation process are described at this level. Citizens are the leading role in smart city sustainability. Moreover, technologies are the media to help citizens participation in activities. At the end of the process, everything has to be evaluated and improved.

Citizens are the people who lived in the city and used city services. Therefore, citizens need to provide feedback to the users of government services. Consultation between citizens and government can be conducted through ICT-based platforms. Several e-Participation research contributions focused on citizens as a crucial role in e-Participation processes.

Technology and e-Participation are interdependencies. Technologies in this context can be defined as hardware and software to help citizens participation. There are many technologies for supporting citizen participation: personal computers, networking hardware, operating system, web-based application for services, and also mobile applications.

Participation activities are a sort of participation process consist of citizen engagement and involvement in the democratic process. Different scope of the democratic processes, such as a national scope or a macro-regional scope has different requirements and characteristics than a local scope.

A participation activity has an outcome. One of the most common problems regarding eParticipation processes is that the government failed to integrate outcomes into the policy process or respond to them effectively. By using technology, e-Participation can do activities, such as e-voting, online decision making, online political discourse, e-consultation, e-activism, e-campaigning, and e- 
petitioning. All of these features will help government systems more productive and reduce several failures.

Evaluations and Improvements are the processes to have better conditions. Every process, actions, and service in e-participations have to be evaluated. The slow process becomes fast. The previous action becomes efficient. In other words, every process, step, and action become better than before.

The third level is the real-time control systems. Once citizens involved many government services, the government needs a system that gives them a real-time and recent report. This level is the way of government to know everything about the participation of their citizens. The use of high-technology systems, such as CCTV (closed-circuit television), the internet, social media, web-based, and mobile applications, ease the government to control every single process. Some smart cities control this system through the command center.

The fourth level, Policies making is the last process from e-Participation in smart cities in which citizens have an active engagement in defining the process and content of policy-making. It acknowledges an equal position for citizens for setting the agenda, although the government has responsibility for the final decision. In the last decade, the leader of the city has to do several offline activities, meetings, and conferences to make the decision. However, e-Participation and technology are getting more accessible, faster and efficient in making decisions or policies.

Few prior research included technology issues in the e-Participation process. In this framework, technology is mandatory for the e-Participation process in smart city systems. The real-time control system is a vital aspect of e-Participation processes, and also it is an essential part of smart city systems. Several previous research on smart city captures frameworks for the development process. However, the novel framework in this book chapter figured out more specific about how the eParticipation process can be adopted in smart cities.

The proposed framework in Fig. 1 complements the previous frameworks of e-participation and smart cities, as described in Table 2 . The advantages of this novel framework are clearly describing how the e-Participation process will implementing for citizens in smart city systems. Fig. 1 shows all of the processes start from the various factors of participation, four critical components, such as citizens, technologies, participation activities, and evaluation and improvement, the whole processes monitored by a real-time control system, and the expectations are helpful for policies making for better services. However, the framework also has a limitation as it has not been implemented in the real smart city case. It is developed based on desk research, as explained in the research method section.

\section{Conclusion}

This research has the conclusion that e-Participation can support sustainable smart city systems through several elements, such as participation factors, citizens, technologies, participation activities, evaluations and improvements, real-time control systems, and policy making. E-Participation is also very important to encourage citizen participation in smart cities. Even though the smart city has sophisticated technologies, but it still needs participation from the citizens and related stakeholders. Additionally, e-Participation has element ' $e$ ' or electronic that identical with smart city systems.

This book chapter contributes a novel framework of e-Participation for smart cities, as shown in Fig. 1. It describes the whole process of e-Participation for smart cities. Furthermore, the novel framework complements the existing frameworks of e-Participation and smart cities by various researchers. It has some implications for the theory, such as the novel framework can be added to the body of knowledge of e-Participation and smart cities fields. Additionally, the implications for practice are the practitioners, stakeholders, and decision-makers regarding smart cities need to consider elements in the framework to improve citizen participation through technologies.

Finally, further interesting research is examining how effective this framework to help and make more natural e-Participation processes in smart city systems, what are the drawbacks and other elements based on empirical research. 


\section{References}

[1] United Nations, "United Nations e-government survey 2012: E-government for the people," New York, New York, USA, 2012.

[2] Ø. Sæbø, J. Rose, and L. Skiftenes Flak, "The shape of eParticipation: Characterizing an emerging research area," Gov. Inf. Q., 2008.

[3] M. Yusuf, C. Adams, and K. Dingley, "Digital citizen participation within schools in the United Kingdom and Indonesia: An Actor-Network Theory (ANT) perspective," Inf., 2016.

[4] E. Anduiza, A. Gallego, and M. Cantijoch, "Online Political Participation in Spain: The Impact of Traditional and Internet Resources,” J. Inf. Technol. Polit., 2010.

[5] A. Macintosh, "Characterizing E-Participation in Policy-Making," in Proceedings of the 37th Hawaii International Conference on System Sciences (HICSS-37), 2004, vol. 00, no. C, p. 50117a (1-10).

[6] E. Tambouris, N. Liotas, and K. Tarabanis, "A framework for assessing eParticipation projects and tools," in Proceedings of the Annual Hawaii International Conference on System Sciences, 2007, pp. 1-10.

[7] E. Kalampokis, E. Tambouris, and K. Tarabanis, "A Domain Model for eParticipation," 2008 Third Int. Conf. Internet Web Appl. Serv., pp. 25-30, Jun. 2008.

[8] C. W. Phang and A. Kankanhalli, "A framework of ICT exploitation for e-participation initiatives," Commun. ACM, vol. 51, no. 12, p. 128, 2008.

[9] M. S. Islam and S. Business, “Towards a sustainable e-Participation implementation model," no. October, pp. $1-12,2008$

[10] S. Scherer and M. A. Wimmer, "A Regional Model for E-Participation in the EU : Evaluation and Lessons Learned from VoicE,” pp. 162-173, 2010.

[11] S. Scherer and M. A. Wimmer, "Reference framework for e-participation projects," in Lecture Notes in Computer Science (including subseries Lecture Notes in Artificial Intelligence and Lecture Notes in Bioinformatics), 2011, vol. 6847 LNCS, pp. 145-156.

[12]M. A. bin Salamat and S. bin Hassan, "An Actor-Network Theory ( ANT ) approach to Malaysian eparticipation framework," in 2011 International Conference on Social Science and Humanity IPEDR, 2011, vol. 5, pp. 83-88.

[13] R. Medaglia, "EParticipation research: Moving characterization forward (2006-2011)," Gov. Inf. Q., vol. 29, no. 3, pp. 346-360, 2012.

[14] M. Yusuf, C. Adams, and K. Dingley, "Research Philosophy and Methodologies of e-Government: Update From ECEG and ICEG," Proc. 14th Eur. Conf. eGovernment (ECEG 2014), vol. 12, no. 2, pp. 242-251, 2014.

[15] S. Scherer and M. A. Wimmer, "A metamodel for the E-participation reference framework," in Lecture Notes in Computer Science (including subseries Lecture Notes in Artificial Intelligence and Lecture Notes in Bioinformatics), 2016.

[16] V. Albino, U. Berardi, and R. M. Dangelico, "Smart Cities: Definitions, Dimensions, Performance, and Initiatives," J. Urban Technol., vol. 22, no. 1, pp. 3-21, 2015.

[17] Y. I. N. Chuantao, X. Zhang, C. Hui, W. Jingyuan, C. Daven, and D. Bertrand, "A literature survey on smart cities," vol. 58, no. October, pp. 1-18, 2015.

[18]N. Alamsyah, T. D. Susanto, and T.-C. Chou, "A Comparison Study of Smart City in Taipei and Surabaya," 2016, pp. 111-118.

[19] J. Bélissent, "Getting clever about smart cities: new opportunities require new business models," Forrester Res. inc, p. 33, 2010.

[20] T. Nam and T. a. Pardo, "Smart city as urban innovation," Proc. 5th Int. Conf. Theory Pract. Electron. Gov. - ICEGOV'11, p. 185, 2011.

[21] M. Batty et al., "Smart cities of the future," Eur. Phys. J. Spec. Top., vol. 214, no. 1, pp. 481-518, 2012. 
[22]J. H. Lee, M. G. Hancock, and M.-C. Hu, "Towards an effective framework for building smart cities: Lessons from Seoul and San Francisco," Technol. Forecast. Soc. Change, vol. 89, pp. 80-99, 2014.

[23]B. Kitchenham et al., "Systematic literature reviews in software engineering-A tertiary study," Inf. Softw. Technol., vol. 52, no. 8, pp. 792-805, 2010.

[24]M. Kehoe et al., "Smarter Cities Series: Understanding the IBM Approach to Smater Cities," IBM Redguides Bus. Leaders, pp. 1-30, 2011.

[25] T. Nam and T. A. Pardo, "Conceptualizing smart city with dimensions of technology, people, and institutions," Proc. 12th Annu. Int. Digit. Gov. Res. Conf. Digit. Gov. Innov. Challenging Times - dg.o '11, p. 282, 2011.

[26]J.-H. Lee and M. G. Hancock, "Towards a Framework for Smart Cities: A Comparison of Seul, San Francisco \& Amsterdam," Yonsei Univ., 2012.

[27]R. Jucevičius, I. Patašienè, and M. Patašius, "Digital Dimension of Smart City: Critical Analysis," Procedia - Soc. Behav. Sci., vol. 156, no. April, pp. 146-150, 2014.

[28] A. Oliveira and M. Campolargo, "From Smart Cities to Human Smart Cities," Proc. 48th Hawaii Int. Conf. Syst. Sci., pp. 2336-2344, 2015.

[29] C. P. Liyanage and A. Marasinghe, "Planning smart meal in a smart city for a smart living," Proc. - 2013 Int. Conf. Biometrics Kansei Eng. ICBAKE 2013, pp. 166-171, 2013.

[30]N. Alamsyah, T.-C. Chou, and T. D. Susanto, "ICT-Mechanisms of Intelligent Transportation System in Taipei City as a Smart City,” Int. J. Comput. Sci. Inf. Technol., vol. 8, no. 3, pp. 55-66, 2016.

[31] G. Kuk and M. Janssen, "The Business Models and Information Architectures of Smart Cities," J. Urban Technol., vol. 18, no. 2, pp. 39-52, 2011.

[32] M. Thite, "Smart cities: implications of urban planning for human resource development," Hum. Resour. Dev. Int., vol. 14, no. 5, pp. 623-631, 2011.

[33]U. Aguilera, O. Peña, O. Belmonte, and D. López-de-Ipiña, "Citizen-centric data services for smarter cities," Futur. Gener. Comput. Syst., pp. 1-14, 2016.

[34]H. Ahvenniemi, A. Huovila, I. Pinto-Sepp??, and M. Airaksinen, "What are the differences between sustainable and smart cities?," Cities, vol. 60, pp. 234-245, 2017.

[35] V. Albino, U. Berardi, and R. M. Dangelico, "Smart Cities : Definitions , Dimensions , Performance , and Initiatives," vol. 0732, no. April, 2016.

[36]P. Neirotti, A. De Marco, A. C. Cagliano, G. Mangano, and F. Scorrano, "Current trends in Smart City initiatives: Some stylised facts," Cities, vol. 38, pp. 25-36, 2014.

[37] J. Hedlund, "Smart City 2020. Technology and Society in the Modern City," no. March, p. 27, 2012.

[38] S. Ben Letaifa, "How to strategize smart cities: Revealing the SMART model," J. Bus. Res., vol. 68, no. 7, pp. 1414-1419, 2015.

[39] a. Macintosh and A. Whyte, "Towards an evaluation framework for eParticipation," Transform. Gov. People, Process Policy, vol. 2, no. 1, pp. 16-30, 2008.

[40]C. Sanford and J. Rose, “Characterizing eParticipation,” Int. J. Inf. Manage., vol. 27, no. 6, pp. 406-421, 2007.

[41]L. Sommer and R. Cullen, "Participation 2 . 0 : a Case Study of e-Participation within the New Zealand Government," 2009 42nd Hawaii International Conference on System Sciences, Big Island, HI, pp. 1-10, 2009. 